\title{
Tecnura
}

INVESTIGACIÓN

\section{Electrocoagulation as an Alternative for the Removal of Chromium (VI) in Solution}

\section{Electrocoagulación como alternativa para eliminación de cromo (VI) en solución}

\author{
Angel Villabona-Ortíz ${ }^{(D)}$, Candelaria Tejada-Tovar (iD) ${ }^{2}$, Rafael Contreras-Amaya ${ }^{3}$
}

Fecha de Recepción: 28 de Septiembre de 2020

Fecha de Aceptación: 24 de Febrero de 2021

Cómo citar: Villabona-Ortíz., A. Tejada-Tovar., C. y Contreras-Amaya., R. (2021). Electrocoagulation as an Alternative for the Removal of Chromium (VI) in Solution. Tecnura, 25(68), 28-42. https:/ / doi.org/10.14483/22487638.17088

\begin{abstract}
Objective: The pollution of water bodies, a product of effluent discharges contaminated with Chromium (VI), is a widely studied environmental problem due to the toxic effects of this pollutant on human health and the environment. The aim of this work is to study the elimination of hexavalent chromium by means of the electrocoagulation method with iron and aluminum electrodes in a monopolar configuration. The effect of residence time, voltage, and the number of electrodes over removal efficiency was evaluated.

Methodology: The experiments were conducted in a $3 \mathrm{~L}$ batch electrocoagulation cell, using 10 and 6 aluminum and stainless-steel plates, respectively, as electrodes connected at a distance of $1,5 \mathrm{~cm}$ in a monopolar configuration and parallel to the power source. Acontaminated solution with $\mathrm{Cr}(\mathrm{VI})$ was treated at a concentration of $50 \mathrm{mg} / \mathrm{L}$, evaluating two levels of residence time (20 and $30 \mathrm{~min})$, voltage (20 and $30 \mathrm{~V})$, and number of electrodes (6 and 10).

Results: Removal percentages between 60,15 and $92,9 \%$ were obtained. It was found that the most positively influential variable in the process is the increase in residence time. It can be inferred that electrocoagulation performs better at lower voltages and longer residence times, and the joint effect of the increase in the number of electrodes and the contact time increases the performance of the process, thus achieving greater removal.

Conclusions: $\mathrm{The} \mathrm{Cr}(\mathrm{IV})$ reduction process by electrocoagulation has the potential to be used for the removal of heavy metals from water in a cost-effective way.

Keywords: $\mathrm{Cr}(\mathrm{VI})$, aluminum electrodes, iron electrodes

\footnotetext{
${ }^{1}$ Master in Environmental Engineering; chemical engineer. Professor at Universidad de Cartagena, Cartagena, Colombia. Email: avillabonao@unicartagena-edu.co

${ }^{2}$ Magister in Environmental Engineering; chemical engineer. Professor at Universidad de Cartagena, Cartagena, Colombia. Email: ctejadat@unicartagena-edu.co

${ }^{3}$ Chemical engineer, graduated from Universidad de Cartagena, Cartagena, Colombia. Email: rcontrerasa01@gmail.com
} 


\section{Resumen}

Contexto: La contaminación de los cuerpos de agua, producto de los vertimientos de efluentes contaminados con Cromo (VI), es una problemática ambiental ampliamente estudiada, debido a los efectos tóxicos de este contaminante sobre la salud humana y el ambiente. El objetivo del presente trabajo es estudiar la eliminación de cromo hexavalente usando el método de electrocoagulación con electrodos de hierro y aluminio en configuración monopolar. Se evaluó el efecto del tiempo de residencia, del voltaje y del número de electrodos sobre la eficiencia de remoción.

Metodología: Los experimentos se realizaron en una celda de electrocoagulación por lotes de 3 L, utilizando 10 y 6 placas de aluminio y acero inoxidable, respectivamente, como electrodos conectados a una distancia de 1,5 cm en configuración monopolar, en paralelo a la fuente de energía. Se trató una solución contaminada con $\mathrm{Cr}(\mathrm{VI})$ a una concentración de50 $\mathrm{mg} / \mathrm{L}$, evaluando dos niveles de tiempo de residencia (20 y $30 \mathrm{~min})$, voltaje (20 y $30 \mathrm{~V}$ ) y número de electrodos (6 y 10 electrodos).

Resultados: Se obtuvieron porcentajes de remoción entre 60,15 y 92,9\%. Se encontró que la variable con mayor incidencia positiva sobre el proceso es el aumento del tiempo de residencia. Se puede inferir que la electrocoagulación se desempeña mejor a voltajes inferiores y tiempos de residencia mayores, y que el efecto conjunto del aumento de la cantidad de electrodos y el tiempo de contacto incrementa el rendimiento del proceso, logrando así mayor remoción.

Conclusiones: El proceso de reducción de cromo (VI) mediante electrocoagulación tiene el potencial de utilizarse para la eliminación de metales pesados del agua de manera rentable.

Palabras clave: $\mathrm{Cr}(\mathrm{VI})$, electrodos de aluminio, electrodos de hierro

\section{Table of Contents}

METHODOLOGY 31

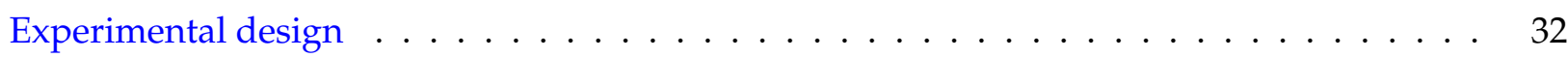

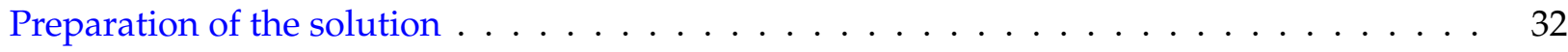

Electrochemical cell design . . . . . . . . . . . . . . . . . 32

$\begin{array}{ll}\text { Electrocoagulation experiments } & 33\end{array}$

$\begin{array}{lc}\text { RESULTS } & 34\end{array}$

$\begin{array}{lc}\text { CONCLUSIONS } & 38\end{array}$

$\begin{array}{lc}\text { FINANCING } & 38\end{array}$

$\begin{array}{lc}\text { ACKNOWLEDGEMENTS } & 38\end{array}$

$\begin{array}{lc}\text { REFERENCES } & 38\end{array}$ 


\section{INTRODUCTION}

Chromium is a metal highly used in industrial processes such as printed circuit board manufacturing, tanning, metal processing, electroplating, and metal finishing. It usually exists in trivalent and hexavalent forms in aqueous solutions (Thirugnanasambandham \& Shine, 2018). Hexavalent chromium $(\mathrm{Cr}(\mathrm{VI}))$, a carcinogen, is toxic to all forms of life and highly soluble in water (Mahmad et al., 2016). On the other hand, trivalent chromium ( $\mathrm{Cr}(\mathrm{III})$ ) has a low solubility in aqueous media, and it easily precipitates at $\mathrm{pH}>4$ as $\mathrm{Cr}(\mathrm{OH})_{3}$ (Genawi et al., 2020).

In the case of wastewaters, $\mathrm{Cr}(\mathrm{VI})$ can be removed with several techniques, such as ion exchange, chemical reduction followed by precipitation, reverse osmosis, photocatalyticprocesses, and adsorption (Nwabanne et al., 2018). The mainstream treatment application currently used to eliminate $\mathrm{Cr}(\mathrm{VI})$ is its reduction to $\mathrm{Cr}(\mathrm{III})$ (Aoudj et al., 2017).

Electro coagulation (EC) is based on the creation of the coagulant while the sacrificial anode is degraded due to the applied current. At the same time, hydrogen is formed at the cathode, thus enabling the removal of contaminants by precipitation and flotation (Elabbas et al., 2016). This technology combines three interdependent processes, which operate jointly to eliminate contaminants: electrochemistry, coagulation, and hydrodynamics. Equations (1) to (4) show the reactions that occur during the removal of $\mathrm{Cr}(\mathrm{VI})$ with an $\mathrm{Al}(\mathrm{III})$ electrode (Sadeghi et al., 2017).

$$
\begin{gathered}
\mathrm{Cr}_{2} \mathrm{O}_{7}^{2-}+14 \mathrm{H}^{+}+6 e^{-} \rightarrow 2 \mathrm{Cr}^{3+}+7 \mathrm{H}_{2} \mathrm{O} \\
\mathrm{HCrO}_{4}^{-}+7 \mathrm{H}^{+}+3 e^{-} \rightarrow \mathrm{Cr}^{3+}+4 \mathrm{H}_{2} \mathrm{O} \\
\mathrm{CrO}_{4}^{2-}+4 \mathrm{H}_{2} \mathrm{O}+3 e^{-} \rightarrow \mathrm{Cr}(\mathrm{OH})_{3}+5 \mathrm{OH}^{-}
\end{gathered}
$$

After the reduction reactions presented above, precipitation of $\mathrm{Cr}^{3+}$ in the form of hydroxide occurs:

$$
\mathrm{Cr}^{3+}+3 \mathrm{OH}^{-} \rightarrow \mathrm{Cr}(\mathrm{OH})_{3}
$$

It can be added that $\mathrm{Al}(\mathrm{OH})_{3}$, if generated from the reaction between $\mathrm{Al}^{3+}$ and $\mathrm{OH}^{-}$ions, is produced on the surface of electrodes. Secondary reactions can occur at the anode if it is powerful enough, such as the reduction of organic compounds by oxidation and $\mathrm{Cl}^{-}$present in the effluents. The $\mathrm{Al}(\mathrm{OH})_{3}$ flocs act as adsorbents or traps for the metal ions and thus remove them from the aqueous media. Additionally, a direct electrochemical reduction of $\mathrm{Cr}(\mathrm{VI})$ to $\mathrm{Cr}(\mathrm{III})$ can occur on the cathode's surface (Singh et al., 2018). At the same time, hydroxyl groups formed at the cathode increase the electrolyte's $\mathrm{pH}$ and can induce co- precipitation of $\mathrm{Cr}(\mathrm{III})$ as hydroxides (Ziati et al., 2018). This happens coordinately to eliminate contaminants present in the water. 
Initially, when using stainless steel as an electrode, there is a process of electrogenerated species of Fe(II), as described in Equation (5):

$$
\mathrm{Fe}^{0}+2 \mathrm{H}_{2} \mathrm{O} \rightarrow \mathrm{Fe}^{2+}+2 \mathrm{H}_{2}+\mathrm{O}_{2}+2 e
$$

This leads to $\mathrm{Cr}(\mathrm{VI})$ reduction to $\mathrm{Cr}(\mathrm{III})$ at $\mathrm{pH}$ between 2 and 6,5, and the precipitation of $\mathrm{Cr}(\mathrm{III})$, produced at $\mathrm{pH}>7,0$ (Elabbas et al., 2020). This process can occur with Al(III) electrodes, and its reaction mechanism is summarized in Equations (1) and (2) (Ali Maitlo et al., 2019). The aforementioned reduction is evidenced by the fact that it takes an acidic medium and a source of $\mathrm{Al}$ (III) to break the balance to the right side (Elabbas et al., 2020). The interaction of $\mathrm{HCrO}_{4}$ - and $\mathrm{CrO}_{4}^{2-}$ ions with iron oxides results in the formation of mono- and bidentate complexes on the surface of the internal sphere. This mechanism is described in Equations (6) and (7) (Ali Maitlo et al., 2019):

$$
\begin{gathered}
\mathrm{Fe}^{+2}(\mathrm{OH})_{3}^{-1}+\mathrm{H}_{2} \mathrm{CrO}_{4}^{-} \rightarrow \mathrm{Fe}^{+3}-\left(\mathrm{HCrO}_{4}^{-}\right)_{3}^{1}+\mathrm{H}_{2} \mathrm{O} \\
\mathrm{Fe}^{+2}(\mathrm{OH})_{2}^{-1}+\mathrm{CrO}_{4}^{2-} \rightarrow \mathrm{FeCrO}_{4}^{-}+\mathrm{H}_{2} \mathrm{O}
\end{gathered}
$$

EC is a technique with an advantage over conventional coagulation due to lower investment costs, maintenance, energy expenditure, efficiency at low concentrations, lower sludge generation, and improved mud quality (Peng \& Guo, 2020). Therefore, it has been widely implemented in the removal of $\mathrm{Cr}(\mathrm{VI})$ using electrodes of different nature. (Prasetyaningrum et al., 2018) reported a $26 \%$ $\mathrm{Cr}(\mathrm{VI})$ removal efficiency using $\mathrm{Al}(\mathrm{II})$ electrodes for $2 \mathrm{~h}$. (Heffron, et al., 2016) found an efficiency of $85 \%$ using Fe(II) electrodes. Similarly, (Ali Maitlo et al., 2019) achieved a $100 \%$ removal rate after $4 \mathrm{~h}$ of operation. Thus, the objective of this study was to evaluate chromium elimination from synthetic solutions through the electrocoagulation method, using aluminum and stainless steel electrodes simultaneously. The effect of voltage variation, number of electrodes, and residence time was determined in this study.

\section{METHODOLOGY}

Potassium chromate $\left(\mathrm{K}_{2} \mathrm{CrO}_{4}\right)$ (PanReac) was used at $98 \%$ purity as a reagent in the preparation of the synthetic solution, as well as 1,5-Diphenylcarbazide as a color indicator in the detection of $\mathrm{Cr}(\mathrm{VI})$ in solutions. The following equipment was also used: an HM Digital Conductivity Meter

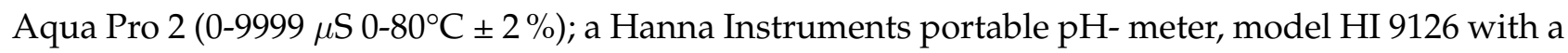
range of 2-16 $\mathrm{pH} \pm 0,01 \mathrm{pH}$; a regulated PHYWE DC-Constanter power supply (0-30 V, 0-20 A); and a Meihua Biobase UV-Vis spectrophotometer, model UV-BK1900 with a $1 \mathrm{~cm}$ quartz cell. 


\section{Experimental design}

A factorial design of experiments was used. The effect of voltage (20 and $30 \mathrm{~V})$, the number of electrodes (6 and 10 electrodes), and the time of residence (20 and $30 \mathrm{~min}$ ) were considered as independent variables. The tests were carried out in duplicate, for a total of 16 experiments.

\section{Preparation of the solution}

The synthetic solution of $\mathrm{Cr}(\mathrm{VI})$ at $50 \mathrm{mg} / \mathrm{L}$ was prepared by dissolving 0,1414 $\mathrm{mg}$ of $\mathrm{K}_{2} \mathrm{CrO}_{4}$ per liter of water (Tejada-Tovar et al., 2020).

\section{Electrochemical cell design}

The design of the cell was made according to (Al-Qodah \& Al-Shannag, 2017). Considering these criteria, a glass cell was built with a thickness of $4 \mathrm{~mm}$ and dimensions of $16 \mathrm{~cm}$ high, $16 \mathrm{~cm}$ wide, and $20 \mathrm{~cm}$ long, with a $3 \mathrm{~L}$ treatment volume of the cell. This design has the possibility of coupling 10 equidistant electrodes at $1,5 \mathrm{~cm}$. The shape of the electrodes was a square plate of $15 \times 15 \mathrm{~cm}$. There were 5 stainless steel electrodes (AISI 316L, caliber 20,0,91 mm thickness), which acted as inert material in the cathode; and 5 aluminum electrodes (caliber 16, 1,67 mm of thickness) as a sacrificial anode. The electrical connection to the PHYWE DC-Constanter power supply was made in a parallel monopolar configuration. The diagram of the electrocoagulation cell is shown in Figure 1.

The current density (I) was determined according to Equation (8):

$$
I\left(\frac{A}{\mathrm{~cm}^{2}}\right)=\frac{\text { Applied current }}{\text { Anode - area }}
$$

The effective area (EA) of the anode is the sum of the exposed (immersed) areas of each electrode of the electrocoagulation cell. Out of each $15 \mathrm{~cm}$ of high plate, $9 \mathrm{~cm}$ are in contact with the water to be treated. Thus, for 6 electrodes, we have an effective area and applied current, as shown in Equations (9) and (10):

$$
\begin{gathered}
E A=3 \text { electrodes } * 2 \text { faces } * 9 \mathrm{~cm} * 15 \mathrm{~cm}=810 \mathrm{~cm}^{2} \\
I_{6 \text {-plates }}=\frac{5 \mathrm{~A}}{810 \mathrm{~cm}^{2}}=0,0062 \mathrm{~A} / \mathrm{cm}^{2}
\end{gathered}
$$

For 10 electrodes, we have the effective area and applied current, as shown in Equations (11) and (12):

$$
\begin{gathered}
E A=5 \text { electrodes } * 2 \text { faces } * 9 \mathrm{~cm} * 15 \mathrm{~cm}=1350 \mathrm{~cm}^{2} \\
I_{6-\text { plates }}=\frac{5 \mathrm{~A}}{1350 \mathrm{~cm}^{2}}=0,0037 \mathrm{~A} / \mathrm{cm}^{2}
\end{gathered}
$$




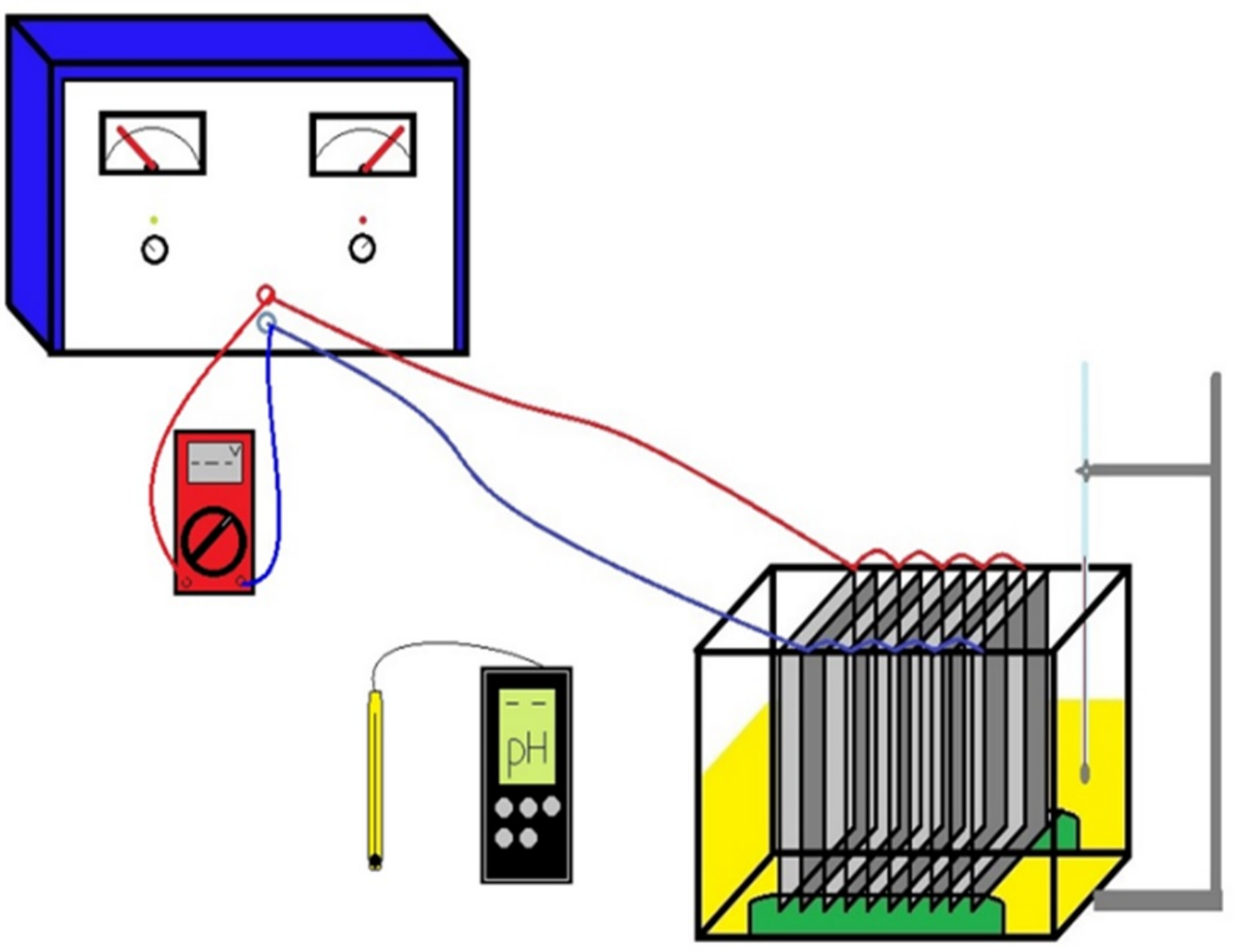

Figure 1. Electrocoagulation equipment

Source: Authors.

\section{Electrocoagulation experiments}

Once the equipment was prepared, $3 \mathrm{~L}$ of $\mathrm{Cr}(\mathrm{VI})$ solution at $50 \mathrm{ppm}$ were added, evaluating the effect of the variables according to the proposed experimental design. After the treatment time had elapsed, the plates were removed from the reactor and left to decant for 30 minutes. The final concentration of $\mathrm{Cr}(\mathrm{VI})$ in the solution was determined by UV-Vis spectrophotometry at $540 \mathrm{~nm}$, following the standard method for the determination of hexavalent chromium in water, by means of the colorimetric complex formed between 1,5- Diphenylcarbazide and the ion (ASTM, 2017). The percentage of removal (RY) was obtained with Equation (13):

$$
R Y(\%)=\frac{C_{\text {in }}-C_{\text {out }}}{C_{\text {in }}} * 100
$$

where $C_{C r(i n)}$ is the initial chromium concentration, and $C_{C r(f i n)}$ is the post-treatment contaminant concentration in $\mathrm{mg} / \mathrm{L}$. 


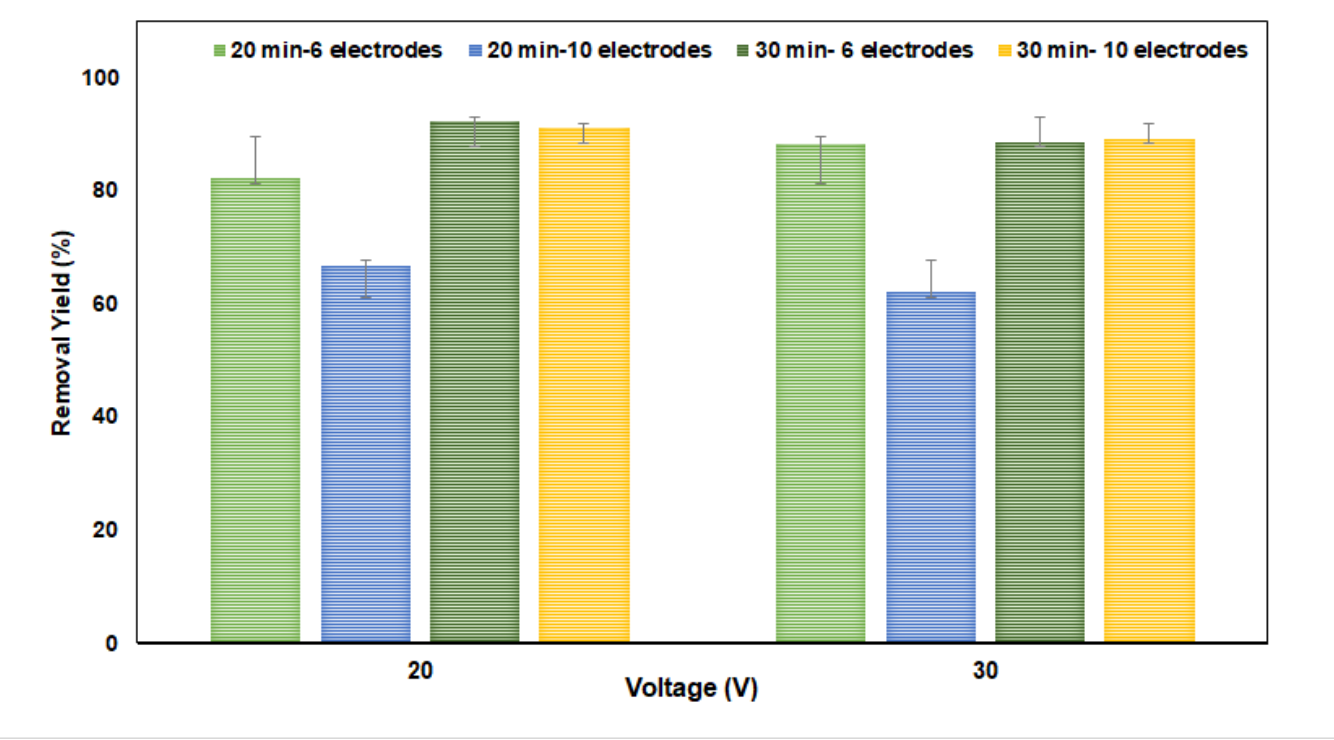

Figure 2. Effect of the number of electrodes, contact time, and voltage variation on the efficiency of $\mathrm{Cr}(\mathrm{VI})$ removal

Source: Authors.

\section{RESULTS}

According to Figure 2, the experimental treatments had a variation in the percentage of removal from 60,15 to $92,9 \%$, with the lowest performance using 10 electrodes, $30 \mathrm{~V}$, and $20 \mathrm{~min}$, while the best experimental condition was at 10 electrodes, $30 \mathrm{~min}$, and $20 \mathrm{~V}$. This removal is due to the fact that the hydrolysis products of aluminum and iron in steel destabilize the $\mathrm{Cr}(\mathrm{VI})$ in the solution, which allows agglomeration and a greater separation of the solution by sedimentation or flotation (Prasetyaningrum et al., 2018).

It has been reported that chromium removal using aluminum electrodes reaches approximately $72,65 \%$, whereas, with stainless steel electrodes, a maximum removal efficiency of $88,35 \%$ is obtained, with the EC process being dependent on the $\mathrm{pH}$, thus obtaining the best performance at acidic pH (3) (Mahmad et al., 2016). Aluminum, steel, and a combination of aluminum-steel electrodes have also been used, finding the best performance with aluminum electrodes. However, they reached only $26 \%$ performance during $2 \mathrm{~h}$ of operation, which is far below the results obtained in this research (Prasetyaningrum et al., 2018). The good performance in the removal process of Cr(VI) obtained in this research could be due to the connection between the electrodes (aluminum to the anode and steel to the cathode) because connecting both metals to the cell increases the presence of iron ions, aluminum, and its hydroxides produced by the hydrolyzation of the metallic plates (Khan et al.,). Previous studies have shown that the efficiency of $\mathrm{Cr}(\mathrm{VI})$ removal using electrochemical met- 


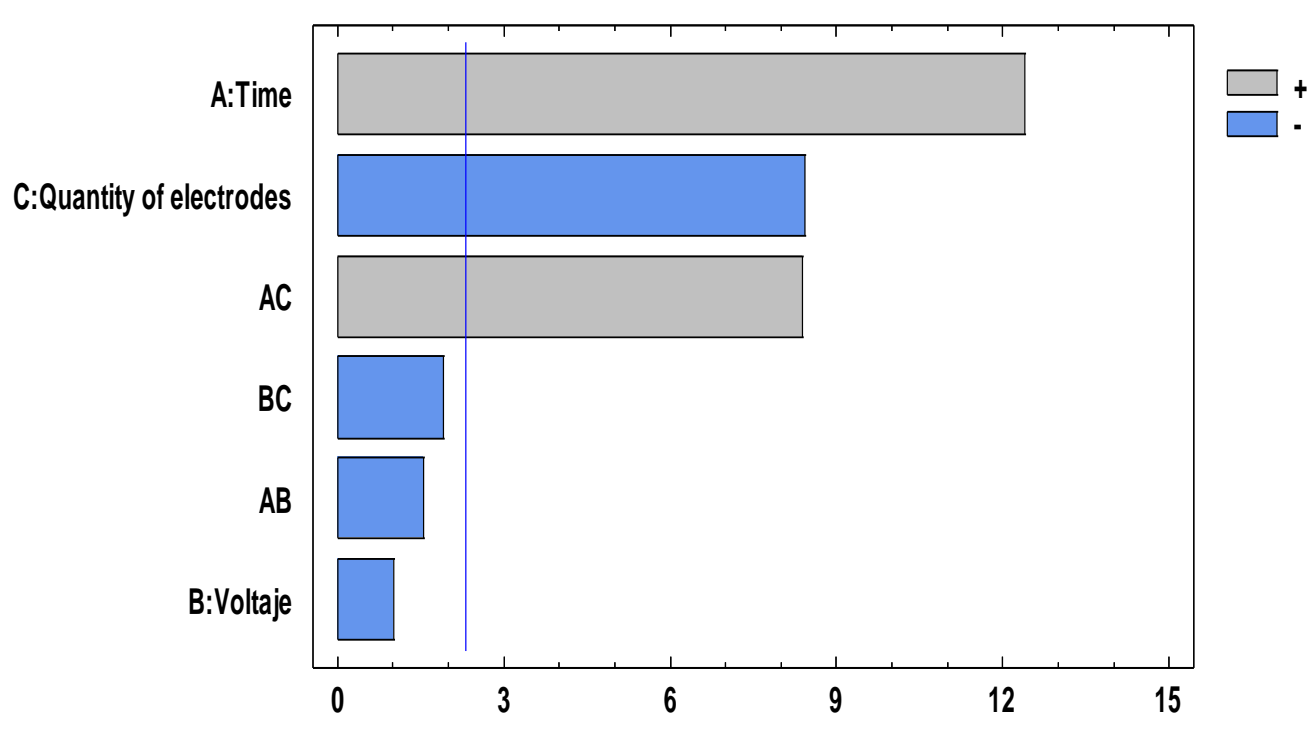

Figure 3. Standardized Pareto chart for $\mathrm{Cr}(\mathrm{VI})$ removal efficiency

Source: Authors.

hods is 100 times better than using precipitation (He et al., 2020). It has been reported, by varying the voltage in 3,6 , and $9 \mathrm{~V}$, that the removal efficiency increased to $34,95,67,357$, and $67,99 \%$, respectively, thus demonstrating the influence of this variable on the efficiency of the process (Pavithra et al., 2020).

The standardized Pareto chart is shown in Figure 3, where it is evident that the residence time has a positive and significantly influential effect on the efficiency of $\mathrm{Cr}(\mathrm{VI})$ removal through EC.

From Figure 3, it can be stated that the increase in the number of electrodes has a negative effect, which is reflected in a lower efficiency when using 10 electrodes, $30 \mathrm{~V}$, and $20 \mathrm{~min}$. On the other hand, voltage variation does not significantly influence the process. It was observed that the simultaneous increase in contact time and the number of electrodes benefits removal efficiency. This could be due to the presence of $\mathrm{Fe}$ (II) and $\mathrm{Al}(\mathrm{III})$ hydroxides, which increases with the number of electrodes. These compounds act as flocculants and trap contaminant molecules, perhaps by means of the proportional increase in $\mathrm{Fe}(\mathrm{II})$ and $\mathrm{Al}(\mathrm{III})$ hydroxides with the number of electrodes. Likewise, the joint effect of the increase in the number of electrodes and the contact time increases the performance of the process, thus achieving a higher removal of $\mathrm{Cr}(\mathrm{VI})$ due to the electrical activity between the electrodes and the voltage supplied to the system. The contact time in the present study varied up to $30 \mathrm{~min}$, because it has been reported in diverse studies that, after this time, there is a decrease in efficiency, which could be due to the effect of the EC reaching the saturation point. Therefore, unlimited growth is not achieved by increasing the reaction time (Liu, 2018). Moreover, as the time increases, the metal plates tend to form a loose protective film passivation layer, which influences the amount of dissolved 
Table I. ANOVA for Cr(VI) removal efficiency

\begin{tabular}{ccccc}
\hline Source & Sum of Squares & Gl & F-Ratio & P-Value \\
\hline A: residence time & 953.266 & 1 & 157,24 & 0,0000 \\
\hline B: voltage & 6,25 & 1 & 1,03 & 0,3397 \\
\hline C: number of electrodes & 441,0 & 1 & 72,74 & 0,0000 \\
\hline AB & 15,0156 & 1 & 2,48 & 0,1542 \\
\hline AC & 435.766 & 1 & 71,88 & 0,0000 \\
\hline BC & 22,5625 & 1 & 3,72 & 0,0898 \\
\hline Blocks & 1,89063 & 1 & 0,31 & 0,5918 \\
\hline Total error & 48,5 & 8 & & \\
\hline Total (corr.) & $\mathbf{1 9 2 4 . 2 5}$ & $\mathbf{1 5}$ & & \\
\hline
\end{tabular}

Source: Authors.

$\mathrm{Al}(\mathrm{III})$ and $\mathrm{Fe}(\mathrm{II})$ electrode and free radicals, resulting in ions and the reduction of the number of flocculants, as well as a decrease in the oxidation effect (Das \& Nandi, 2020). Another important criterion to consider in the implementation of EC is energy consumption, which is affected by the increasing time, thus implying higher processing costs (Chouhan et al., 2018).

The analysis of variance (ANOVA) is shown in Table I, which indicates the significance of the variables in the ranges evaluated in the process of $\mathrm{Cr}(\mathrm{VI})$ removal by $\mathrm{EC}$, with a p-value of less than 0,05, thus corroborating what is found in the Pareto chart in Figure 3.

Based on the ANOVA of the experimentally obtained data, the statistical significance of the adjusted equation was estimated by using the established variance ratio and the determination coefficients $\left(\mathrm{R}^{2}\right)$. It can be inferred from the quadratic model that it was statistically significant for the efficiency of $\mathrm{Cr}(\mathrm{VI})$ removal by EC ( $\mathrm{p} \geq 0,0001$ ). The results showed that only 3 of the 7 model terms were significant for removal efficiency: residence time (A), the number of electrodes (C), and AC interaction term (Emamjomeh et al., 2017). The $\mathrm{R}^{2}$ was higher than $90 \%$; it showed that the variability in the adsorption could be explained by the model, with the coherence between the experimental and predicted values being significant within the process.

$$
R Y(\%)=124,462+1,6625 * A+1,49375 * B+1207031 * C-0,03875 * A B+0,5219 * A C-0,1188 * B C
$$

where $R Y$ is the percentage of removal efficiency, $A$ is the residence time in min, B is the voltage in $V$, and $C$ is the number of electrodes.

Figure 4 shows the effect of time on the $\mathrm{C} / \mathrm{Ci}$ ratio of $\mathrm{Cr}(\mathrm{VI})$ for different applied voltages and the number of electrodes used at an initial concentration of $50 \mathrm{mg} / \mathrm{L}$. 


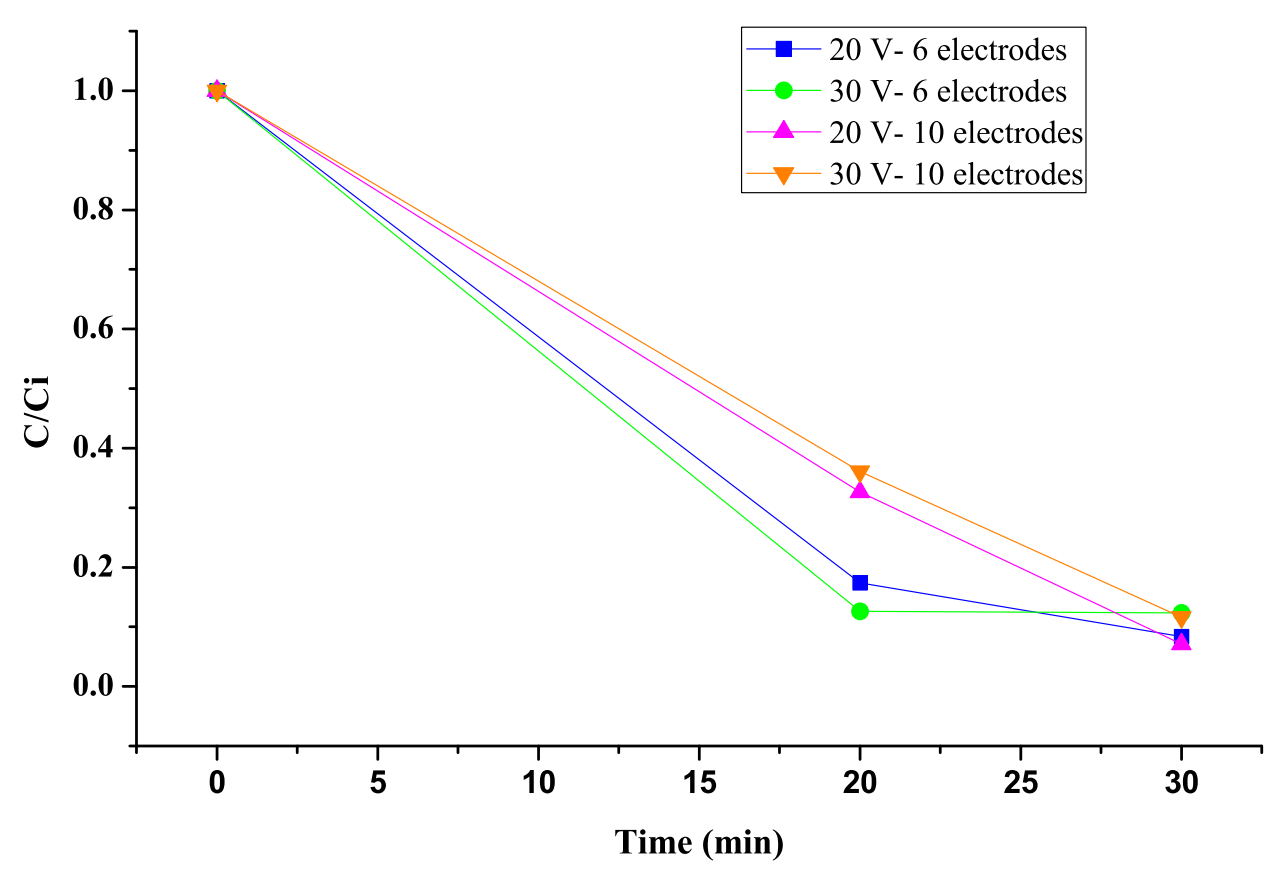

Figure 4. Effect of time in the $\mathrm{Cr}(\mathrm{VI})$ removal

Source: Authors.

It is observed that the $\mathrm{pH}$ varied from an alkaline medium $(10,5)$ to a basic medium $(6,8-7)$. This is due to the precipitation and flotation of the chromium present in the solution, leaving water with small traces of chromium in the center of the reactor, as reported by (?). In this regard, the speciation of chromium in aqueous solutions depends on different physical parameters such as temperature, $\mathrm{pH}$, the presence of another compounds, and concentration. Nevertheless, it has been discovered that $\mathrm{Cr}(\mathrm{VI})$ can be found as $\mathrm{HCrO}_{4}^{-}, \mathrm{CrO}_{4}^{2-}$, or $\mathrm{Cr}_{2} \mathrm{O}_{7}^{2-}$ (Martín-Domínguez et al., 2018). Thus, complex formation at the electrodes is expected because of the high state of oxidation of Chromium (Babakhouya etal., 2019). In this sense, it was demonstrated that the $\mathrm{Cr}(\mathrm{VI})$ reduction process depends on the acidity of the medium, and a greater efficiency was obtained in acidic mediums, which could be attributed to the fact that existing $\mathrm{Cr}(\mathrm{VI})$ species such as $\mathrm{Cr}_{2} \mathrm{O}_{7}^{2-}$ are more easily reduced under acidic conditions than under neutral/alkaline conditions, according to (Peng et al., 2019).

From Figure 4, it can be inferred that the variation in voltage does not significantly affect removal because, regardless of the voltage used, most experiments yielded removal percentages very close to and even higher than $90 \%$ (Aboulhassan et al., 2018). The best removal efficiency is given by using the configuration of 10 electrodes at $20 \mathrm{~V}$ for $30 \mathrm{~min}$, which was due to the interaction of the number of sacrificial electrodes and the residence time, the most influential parameters in the process. This was made evident in the 30 min experiments; they obtained higher removal percentages than the $20 \mathrm{~min}$ 
treatments, which is very close to and higher than $90 \%$. By increasing the number of electrodes and keeping the current density constant, the rate of all the reactions increases as a consequence of the increase of the anode's effective surface (Mamelkina et al., 2019). That is, by increasing the number of electrodes in the treatment, a higher concentration of aluminum in dissolution is achieved in a shorter time (Petrie et al., 2015). It is evident that, when there is a greater number of electrodes, the same removal percentage can be achieved in less time than with a smaller number of electrodes, which is why the fraction of precipitated chromium is directly proportional to the number of electrodes (Kim et al., 2020).

\section{CONCLUSIONS}

The results obtained showed efficiency in the removal of hexavalent chromium up to $92,9 \%$ using 10 electrodes and $20 \mathrm{~V}$ for $30 \mathrm{~min}$. Thus, electrocoagulation performs better at lower voltages and longer residence times. The $\mathrm{Cr}(\mathrm{VI})$ reduction process was significantly affectedby the residence time and the number of electrodes, due to the increased anode area. Electrocoagulation technology can be considered a viable alternative for the treatment of wastewater with hexavalent chromium because it allows the removal of a large amount of the contaminant in a single operation. Furthermore, chemical coagulants are not used as in conventional methods, thus making it an environmentally friendly treatment option.

\section{FINANCING}

The University of Cartagena provided the materials, reagents, equipment, and human resources (research professors) required to carry out the project entitled Removal of chromium (VI) using electrocoagulation as an alternative treatment of contaminated water from the electroplating industry".

\section{ACKNOWLEDGEMENTS}

The authors are grateful to the University of Cartagena for the support in developing this research.

\section{REFERENCES}

[Aboulhassan et al., 2018] Aboulhassan, M. A., El Ouarghi, H., Ait Benichou, S., Ait Boughrous, A., $\&$ Khalil, F. (2018). Influence of experimental parameters in the treatment of tannery wastewater by electrocoagulation. Separation Science and Technology (Philadelphia), 53(17), 2717-2726. https:

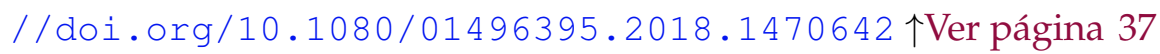


[Al-Qodah \& Al-Shannag, 2017] Al-Qodah, Z. \& Al-Shannag, M. (2017). Heavy metal ions removal from wastewater using electrocoagulation processes: A comprehensive review. Separation Science andTechnology (Philadelphia), 52(17), 2649-2676. https://doi.org/10.1080/01496395. 2017.1373677 ^Ver página 32

[Ali Maitlo et al., 2019] Ali Maitlo, H., Kim, K. H., Yang Park, J., \& Hwan Kim, J. (2019). Removal mechanism for chromium (VI) in groundwater with cost-effective iron-air fuel cell electrocoagulation. Separation and Purification Technology, 213, 378-388. https://doi.org/10.1016/j. seppur.2018.12.058 ^Ver página 31

[ASTM, 2017] (ASTM, 2017) D1687- 17. Standard Test Methods for Chromium in Water. ASTM International. https://doi.org/10.1520/D1687-17个Ver página

[Aoudj et al., 2017] Aoudj, S., Cheknane, B., Zemmouri, H., Zermane, F., Khelifa, A., Hecini, M., \& Drouiche, N. (2017). Kinetics and adsorption isotherm for the removal of fluoride and chromium (VI) from wastewater by electrocoagulation. Desalination and Water Treatment, 82, 262-270. https : //doi.org/10.5004/dwt.2017.21017 ^Ver página 30

[Babakhouya etal., 2019] Babakhouya, N., Abdouni, M., \& Louhab, K. (2019). Electrochemical chromium(VI) recovery process by conducting composite, Olive Pomace/Pani. Revue Roumaine de Chimie, 64(9), 747-753. https://doi.org/10.33224/rrch.2019.64.9.01 个Ver página 37

[Chouhan et al., 2018] Chouhan, A., Thakur, L. S., Patidar, K., \& Varma, A. K. (2018). A Review on Removal of Heavy Metals from Water / Wastewater by Electrocoagulation Process. International Research Journal of Engineering and Technology (IRJET), 5(12), 934-944. https : / www . ir jet . net / archives/V5/i12/IRJET-V5I12179.pdf $\uparrow$ Ver página 36

[Das \& Nandi, 2020] Das, D. \& Nandi, B. K. (2020). Removal of Hexavalent Chromium from Wastewater by Electrocoagulation (EC): Parametric Evaluation, Kinetic Study and Operating Cost. Transactions of the Indian Institute of Metals, 73, 2053-2060. https://doi.org/10.1007/ s12666-020-01962-4 个Ver página 36

[Elabbas et al., 2016] Elabbas, S., Ouazzani, N., Mandi, L., Berrekhis, F., Perdicakis, M., Pontvianne, S., Pons, M. N., Lapicque, F., \& Leclerc, J. P. (2016). Treatment of highly concentrated tannery wastewater using electrocoagulation: Influence of the quality of aluminium used for the electrode. Journal of Hazardous Materials, 319, 69-77. https : / / doi . org/10.1016/j · jhazmat . 2015. $12.067 \uparrow$ Ver página 30

[Elabbas et al., 2020] Elabbas, S., Adjeroud, N., Mandi, L., Berrekhis, F., Pons, M. N., Leclerc, J. P., \& Ouazzani, N. (2020). Eggshell adsorption process coupled with electrocoagulation for improvement of chromium removal from tanning wastewater. International Journal of Environmental Analy- 
tical Chemistry. Advance online publication. https://doi.org/10.1080/03067319.2020. $1761963 \uparrow$ Ver página 31

[Emamjomeh et al., 2017] Emamjomeh, M. M., Jamali, H. A., \& Moradnia, M. (2017). Optimization of nitrate removalefficiency and energy consumption using a batch monopolar electrocoagulation: Prediction by RSM method. Journal of Environmental Engineering, 143(7), 04017022. https : / / doi . org/10.1061/(ASCE) EE.1943-7870.0001210 ^er página 36

[Genawi et al., 2020] Genawi, N. M., Ibrahim, M. H., El-Naas, M. H., \& Alshaik, A. E. (2020). Chromium removal from tannery wastewater electrocoagulation: Optimization and sludge characterization. Water, 12(5), 1374. https: / / doi .org/10.3390/W12051374 个Ver página 30

[He et al., 2020] He, C., Gu, L., Xu, Z., He, H., Fu, G., Han, F., Huang, B., \& Pan, X. (2020). Cleaning chromium pollution in aquatic environments by bioremediation, photocatalytic remediation, electrochemical remediation and coupled remediation systems. Environmental Chemistry Letters, 18(3), 561-576. https://doi.org/10.1007/s10311-019-00960-3个Ver página 35

[Heffron, et al., 2016] Heffron, J., Marhefke, M., \& Mayer, B. K. (2016). Removal of trace metal contaminants from potable water by electrocoagulation. Scientific Reports, 6, 28478. https://doi . org/10.1038/srep28478 个Ver página 31

[Khan et al.,] Khan, S. U., Islam, D. T., Farooqi, I. H., Ayub, S., \& Basheer, F. (2019). Hexavalent chromium removal in an electrocoagulation column reactor: Process optimization using CCD, adsorption kinetics and $\mathrm{pH}$ modulated sludge formation. Process Safety and Environmental Protection, 122, 118-130.https://doi.org/10.1016/j.psep.2018.11.024 个Ver página 34

[Kim et al., 2020] Kim, T., Kim, T. K., \& Zoh, K. D. (2020). Removal mechanism of heavy metal (Cu, $\mathrm{Ni}, \mathrm{Zn}$, and $\mathrm{Cr}$ ) in the presence of cyanide during electrocoagulation using Fe and $\mathrm{Al}$ electrodes. Journal of Water Process Engineering, 33, 101109. https://doi.org/10.1016/j.jwpe.2019. $101109 \uparrow$ Ver página 38

[Liu, 2018] Liu, T., He, F., An, C., Kang, X., Huang, Z., Li, W., \& Zhang, Y. (2018). Experimental study on the treatment of chromium containing wastewater by electric flocculation. IOP Conference Series: Earth and Environmental Science, 170(5). https: / / doi .org/10.1088/1755-1315/170/5/ 052012 个er página 35

[Mahmad et al., 2016] Mahmad, M. K. N., Rozainy, M. A. Z. M. R., Abustan, I., \& Baharun, N. (2016). Electrocoagulation Process by Using Aluminium and Stainless Steel Electrodes to Treat Total Chromium, Colour and Turbidity. Procedia Chemistry, 19,681-686. https://doi.org/10.1016/j . proche.2016.03.070 个Ver página 30,34 
[Mamelkina et al., 2019] Mamelkina, M. A., Vasilyev, F., Tuunila, R., Sillanpää, M., \& Häkkinen, A. (2019). Investigation of the parameters affecting the treatment of mining waters by electrocoagulation. Journal of Water Process Engineering, 32, 100929. https:// doi.org/10.1016/j.jwpe. 2019.100929 $\uparrow$ Ver página 38

[Martín-Domínguez et al., 2018] Martín-Domínguez, A., Rivera-Huerta, M. L., Pérez-Castrejón, S., Garrido-Hoyos, S. E., Villegas-Mendoza, I. E., Gelover-Santiago, S. L., Drogui, P., \& Buelna, G. (2018). Chromium removal from drinking water by redox-assisted coagulation: Chemical versus electrocoagulation. Separation and Purification Technology, 200, 266-272. https://doi . org/10 . $1016 / j$.seppur.2018.02.014 个Ver página 37

[Naghdali et al., 2019] Naghdali, Z., Sahebi, S., Ghanbari, R., Mousazadeh, M., \& Jamali, H. A. (2019). Chromium removal and water recycling from electroplating wastewater through direct osmosis: Modeling and optimization by response surface methodology. Environmental Health Engineering and Management, 6(2),113-120. https://doi.org/10.15171/ehem.2019.13 个er página

[Nwabanne et al., 2018] Nwabanne, J. T., Igwegbe, C. A., \& Okpo, S. O. (2018). Removal of Copper, Nickel, and Chromium from Simulated Wastewater using Electrocoagulation Technique. 2018 International Conference Proceedings: Faculty of Engineering, Unizik, August, 448- 458. https:// www.researchgate.net/publication/327043937 https://doi.org/10.1155/2018/ 4349639 个er página 30

[Pavithra et al., 2020] Pavithra, K. G., Jaikumar, V., Kumar, P. S., \& Sundarrajan, P. (2020). Cleaner strategies on the effective elimination of toxic chromium from wastewater using coupled electrochemical/biological systems. Environmental Progress and Sustainable Energy,39(4), e13399. https://doi.org/10.1002/ep.13399 个Ver página 35

[Peng \& Guo, 2020] Peng, H. \& Guo, J. (2020). Removal of chromium from wastewater by membrane filtration, chemical precipitation, ion exchange, adsorption electrocoagulation, electrochemical reduction, electrodialysis, electrodeionization, photocatalysis and nanotechnology: a review. Environmental Chemistry Letters, 18, 2088-2068. https://doi.org/10.1007/ s10311-020-01058-x $\uparrow$ Ver página 31

[Peng et al., 2019] Peng, H., Leng, Y., \& Guo, J. (2019). Electrochemical removal of chromium (VI) from wastewater.Applied Sciences, 9(6), 1156. https://doi .org/10.3390/app9061156 ^Ver página 37

[Petrie et al., 2015] Petrie, B., Barden, R., \& Kasprzyk-Hordern, B. (2015). A review on emerging contaminants in wastewaters and the environment: Current knowledge, understudied areas and recommendations for future monitoring. Water Research, 72, 3-27. https://doi .org/10.1016/ J.WATRES.2014.08.053 https://doi.org/10.3390/app9061156 个Ver página 38 
[Prasetyaningrum et al., 2018] Prasetyaningrum, A., Jos, B., Dharmawan, Y., Prabowo, B. T., Fathurrazan, M., \& Fyrouzabadi. (2018). The influence of electrode type on electrocoagulation process for removal of chromium (VI) metal in plating industrial wastewater. Journal of Physics: Conference Series, 1025, 012126. https://doi .org/10.1088/1742-6596/1025/1/012126 †er página 31,34

[Sadeghi et al., 2017] Sadeghi, S., Alavi Moghaddam, M. R., \& Arami, M. (2017). Techno-economical evaluation of hexavalent chromium removal by electrocoagulation process with the aid of polyaluminum chloride as coagulant: Optimization through response surface methodology. Environmental Engineering and Management Journal, 16(1), 93-104. https:// doi .org/10.30638/eemj. 2017. $011 \uparrow$ Ver página 30

[Singh et al., 2018] Singh, H., Sonal, S., \& Mishra, B. K. (2018). Hexavalent chromium removal by monopolar electrodes based electrocoagulation system: Optimization through Box-Behnken design. Journal of Water Supply: Research and Technology - AQUA, 67(2), 147-161. https : / / doi . org/ 10 . $2166 /$ aqua. $2017.135 \uparrow$ Ver página 30

[Tejada-Tovar et al., 2020] Tejada-Tovar, C., Villabona-Ortíz, A., \& Ortega-Toro, R. (2020). Determination of Kinetic Parameters in the Biosorption of Chromium (VI) in Aqueous Solution. Ingeniería y Ciencia, 16(31), 129-143. https://doi.org/10.17230/ingciencia.16.31.6 https: //doi.org/10.2166/aqua.2017.135 个Ver página 32

[Thirugnanasambandham \& Shine, 2018] Thirugnanasambandham, K. \& Shine, K. (2018). Investigation on the Removal of Chromium from Wastewater using Electrocoagulation. International Journal of Chemical Reactor Engineering, 16(5), 1-10. https://doi .org/10.1515/ijcre-2017-0155 https://doi.org/10.2166/aqua.2017.135 个er página 30

[Ziati et al., 2018] Ziati, M., Khemmari, F., Aitbara, A., \& Hazourli, S. (2018). Reduction of Turbidity and Chromium Content of Tannery Wastewater by Electrocoagulation Process. Water Environment Research,90(7),598-603. https: / / doi .org/10 .2175/106143017x15131012152906 $\uparrow$ Ver página 30

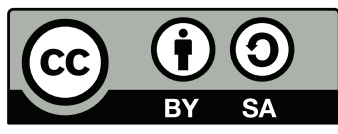

